\title{
Evaluation of volcanic gas reservoir in Yingcheng formation of Block Shengshen2-1 of Northern Part of Songliao Basin
}

\author{
ZHOU Yue, Wu Haibo \\ Exploration and Development Research Institute of Daqing Oil Field Co. Ltd; Daqing City; Heilongjiang Province; 163712
}

\begin{abstract}
According to the thin sections of volcanic rocks, chemical composition analysis and log interpretation, and well data, it is determined that the volcanic rocks of Yingcheng Formation in Shengshen 2-1 block are mainly intermediate-acid volcanic lava and pyroclastic rocks. Through physical analysis of core samples, it is considered that Shengshen 2-1 block belongs to low-porosity and low-permeability reservoir. Microfracture-fracture is relatively developed in the compact section, and fracture is not developed in the porous section. Microfracture and reticular fracture can be seen in the thin section. Statistical analysis of porosity and density of volcanic reservoir shows that volcanic rock density below 2.53 can be used as reservoir. According to the relationship between reservoir space and gas content, the characteristics of volcanic lithology, lithofacies and reservoir space, the reservoir in this block can be divided into four types.
\end{abstract}

Block Shengshen 2-1 is located in Shengping nose structure which extending southward from the low uplift of song station, Xujiaweizi fault depression in Songliao basin. The main target formation here for gas exploration is yingcheng formation. Yingcheng formation was divided into sections, and only Ying3, the third sections and Ying4, the fourth sections in this area. Ying3 is 200 to 760 meters thick. The lithologies of Ying3 are mainly widely distributed layered acid volcanic eruption rocks and a small amount of intermediate eruption rocks, sandy conglomerates and tuffaceous siltstones sandwiched between them. The common rock types are rhyolite, volcanic breccia, lava tuff, andesite and andesite basalt. Ying4 is less than 20 meters thick, and its lithologies are tuffaceous coarse sandstone and mudstone, and it has unconformity contact with underlying strata.

\section{Petrological characteristics}

The volcanic rocks of yingcheng formation in block shengshen 2-1 are mainly intermediate-acid volcanic rocks, including pyromeride, rhyolite, perlite, trachy dacite, trachyte and basaltic trachyandesite and pyroclastic rocks, including Rhyolite fused tuff, Rhyolitic crystal tuff, Rhyolitic breccia tuff, Rhyolite volcanic breccias and agglomerate [1].

\subsection{Rhyolite}

There are four types of rhyolites in block shengshen 2-1, pyromeride, porous rhyolite, silicated rhyolite, and cataclastic rhyolites.

The rhyolite here is gray or grayish white, dense and hard, fractured, having porphyritic structure. The mainly consists of porphyry are feldspar and quartz. Feldspar is idiomorphic or subhedron, surface weathered, with glass luster. Quartz is subhedron or heteromorphic, transparent with round edge and oily luster, $1-2 \mathrm{~mm}$ in diameter. The quartz content is about $10 \%$. The matrix of rhyolite is composed of spherulitic or radial silica or cryptocrystalline mineral. A small number of pores can be observed under magnifying glass, carbonate metasomatism was observed in some cuttings. Local porphyritization and kaolinization of rocks occurred.

The reservoir space of rhyolites mainly consists of pores, residual pores after the pores are filled and internal pores of almond, micro-pores generated by the devitrification of rhyolite glass, pores generated by the dissolution of feldspar and carbonate minerals, and microcracks developed locally.

\subsection{Tuff}

The tuff types in this block are mainly rhyolite rystalline tuff followed by fused tuff. Rhyolite crystalline tuff is characterized by dense, hard, pyroclastic material $>90 \%$, no or little plasticoclastic, particle size of $2-50 \mathrm{~mm}$, lamellar structure is not obvious, mainly compaction. The crystal chips are composed of feldspar and quartz, Quartz is subhedron, round edge, transparent, with an oily luster. Feldspar is subhedron, with glass luster, mostly kaolinized and stomata developed. Pyrite is occasionally found in the chips. The matrix has cryptocrystalline structure and orphyritization.

The fused tuff is mainly composed of plastic detritus. Pyroclastic is less than $2 \mathrm{~mm}$, in addition to quartz chip, feldspar chip, there are more pulp chip, pulp chip stretched, nearly the same arrangement. The fused tuff has pseudorhyolite and block structure. According to the

\footnotetext{
* Corresponding author: 47310372@qqq.com
} 
characteristics of the volcanic clastic material, it can be divided into breccia-bearing clastic fused tuff, rhyolitic breccia-bearing clastic magmatic clastic fused tuff and rhyolitic crystal clastic fused tuff.

The reservoir space of fused tuff mainly includes the dissolution of volcanic ash, plastic cuttings and pores existing in the cuttings, residual pores after the pores are filled and the internal pores of almond, pores generated by the dissolution of feldspar and carbonate minerals, and micro-cracks developed locally.

\subsection{Volcanic breccias}

Volcanic breccias are mainly composed of rhyolite, crystalline tuff and siliceous rocks, and a small amount of andesite and calcite are found locally. Pyroclastic materials $>90 \%$, with no or little plastic detritus, angular, different sizes and poor sorting. Volcanic ash cement, dense, hard, rock with volcanic motley structure, block structure; The gray-white and gray-green volcanic breccia rocks are more seriously kaolinized and occasionally silicified.

The reservoir space of volcanic breccia is mainly due to the dissolution of volcanic ash, pores in cuttings and amygdales pores, pores produced by dissolution of feldspar and carbonate minerals, locally developed microcracks and cracks between breccia and so on.

\section{Reservoir properties}

The pore types of volcanic rock reservoirs in block Shengshen 2-1 mainly include: primary pores, internal pores of amygdales, demolitization pores in rhyolite, dissolution holes in feldspar, micropores in matrix, contraction joints and fractures around spherules (Table 1). Structural fractures connect the above pores and the combination of pores and micro-fractures is the main gasproducing reservoir in this area [2].

Table 1. Proportion of main pore types in different rock types.

\begin{tabular}{|c|c|c|c|c|c|c|}
\hline \multirow[b]{2}{*}{ Rock type } & \multirow[b]{2}{*}{$\begin{array}{c}\text { primary } \\
\text { pore }\end{array}$} & \multicolumn{5}{|c|}{ secondary pore } \\
\hline & & $\begin{array}{c}\text { Demoli } \\
t- \\
\text { ization } \\
\text { pore }\end{array}$ & $\begin{array}{c}\text { Feldspar } \\
\text { dissolutio } \\
\text { n pore }\end{array}$ & $\begin{array}{c}\text { volcanic } \\
\text { ash } \\
\text { dissolutio } \\
\text { n pore }\end{array}$ & $\begin{array}{c}\text { Inter- } \\
\text { gravel } \\
\text { pore }\end{array}$ & $\begin{array}{c}\text { micro- } \\
\text { fractur } \\
\mathrm{e}\end{array}$ \\
\hline $\begin{array}{c}\text { Granular } \\
\text { rhyolite }\end{array}$ & 69.25 & 22.89 & 3.67 & 0.00 & 0.00 & 4.20 \\
\hline $\begin{array}{c}\text { Rhyolitic } \\
\text { tuff }\end{array}$ & 16.67 & 0.00 & 0.00 & 72.22 & 0.00 & 11.11 \\
\hline $\begin{array}{l}\text { Rhyolitic } \\
\text { fused tuff }\end{array}$ & 11.11 & 0.00 & 0.00 & 88.89 & 0.00 & 0.00 \\
\hline
\end{tabular}

According to the statistical results, the primary storage spaces of spherulite rhyolite are mainly primary pores, followed by demolitization pores and a few microfractures. Rhyolitic tuff storage spaces is mainly composed of pozzolanic dissolved pores, followed by primary pores and a few micro-fractures. Volcanic breccia storage spaces is mainly composed of intergravel pores and pore-dissolved pores, followed by primary pores, feldspar dissolved pores and a few microfracture pores [3].
Table 2 Pore Characteristics determined by MIP

\begin{tabular}{|c|c|c|c|c|}
\hline Class & A & B & $\mathrm{C}$ & $\mathrm{D}$ \\
\hline Pcd(Mpa) & $<2.75$ & $2.75-8.75$ & $8.75-24.15$ & $>24.15$ \\
\hline Pc50(Mpa) & $<5.85$ & $5.85-15.7$ & $15.7-37.2$ & $>37.2$ \\
\hline $\mathrm{We}(\%)$ & $>35.8$ & $28.9-35.8$ & $17.6-28.9$ & $<17.6$ \\
\hline $1 / \mathrm{D}$ & $<0.030$ & $0.030-0.075$ & $0.075-0.195$ & $>0.195$ \\
\hline$\varphi$ & $<0.10$ & $0.10-0.85$ & $0.85-5.20$ & $>5.20$ \\
\hline $\operatorname{Smax}(\%)$ & $<27.50$ & $27.50-75.00$ & $75.00-90.00$ & $>90.00$ \\
\hline Smin $(\%)$ & $>72.43$ & $23.83-72.43$ & $23.83-9.59$ & $<9.59$ \\
\hline $\operatorname{Sr}(\%)$ & $<31.38$ & $31.38-54.49$ & $54.49-71.34$ & $>71.34$ \\
\hline VРТ (\%) & $<3.00$ & $3.00-4.75$ & $4.75-9.25$ & $>9.25$ \\
\hline $\operatorname{Ra}(\mu \mathrm{m})$ & $>3.500$ & $0.350-3.500$ & $0.085-0.350$ & $<0.085$ \\
\hline $\mathrm{Rp}(\mu \mathrm{m})$ & $<0.028$ & $0.028-0.085$ & $0.085-0.167$ & $>0.167$ \\
\hline $\mathrm{R}_{50}(\mu \mathrm{m})$ & $<0.004$ & $0.004-0.048$ & $0.048-0.13$ & $>0.13$ \\
\hline $\mathrm{Sp}$ & $<1$ & $1-1.4$ & $1.4-2.0$ & $>2.0$ \\
\hline $\mathrm{D}$ & $<7.15$ & $7.15-26.60$ & $26.60-95.40$ & $>95.40$ \\
\hline$\alpha$ & $<0.27$ & $0.27-0.37$ & $0.37-0.47$ & $>0.47$ \\
\hline $\mathrm{Kp}$ & $<0.5$ & $0.5-0.7$ & $0.7-1.2$ & $>1.2$ \\
\hline Skp & $<0.015$ & $0.014-0.315$ & $0.315-0.430$ & $>0.430$ \\
\hline
\end{tabular}

The pore radius is very small, most are less than $1 \mu \mathrm{m}$. The pore-throat radius is even smaller, the median pore radius is $0.004-1.49 \mu \mathrm{m}$. The pore throat was mainly of small to medium size and distributed in two sections, $0.016-0.040 \mu \mathrm{m}$ and $0.063-0.250 \mu \mathrm{m}$. Macropore is not the main rarely seen here. Based on well gas production ,the median pore-throat radius is divided into four categories. Class $\mathrm{A}$, the median pore-throat radius value is greater than $0.13 \mu \mathrm{m}$. Class $\mathrm{B}$, the median pore-throat radius value is $0.048-0.13 \mu \mathrm{m}$. Class $\mathrm{C}$, the median pore-throat radius value is $0.004-0.048 \mu \mathrm{m}$. Class $\mathrm{D}$, less than $0.004 \mu \mathrm{m}$, even can't be detected.

\section{Reservoir evaluation}

Through comprehensive analysis, it is concluded that block Shengshen 2-1 belongs to low-porosity and lowpermeability reservoir (Table 3). Microfractures were relatively developed in the dense section, but not in the stomatal section. Microcracks and reticular cracks were seen in the thin sections. The porosity of core analysis was $4.0-27.5 \%$ with an average of $10.45 \%$, and the 
permeability was $0.1-10.0 \times 10^{-3} \mu \mathrm{m}^{2}$ with an average of $0.86 \times 10^{-3} \mu \mathrm{m}^{2}$. According to logging interpretation, the porosity ranges from 4.0 to $28.0 \%$ with an average of $8.0 \%$, and the permeability ranges from 0.1 to $10.0 \times 10^{-}$ ${ }^{3} \mu \mathrm{m}^{2}$ with an average of $0.52 \times 10^{-3} \mu \mathrm{m}^{2}$ [4].

Table 3. Reservoir physical properties of different rock types.

\begin{tabular}{|c|c|c|c|}
\hline Rock type & $\begin{array}{c}\text { porosity } \\
(\%)\end{array}$ & $\begin{array}{c}\text { permeability } \\
\left(\mu \mathrm{m}^{2}\right)\end{array}$ & $\begin{array}{c}\text { Reservoir } \\
\text { Physical } \\
\text { Property } \\
\text { Evaluation }\end{array}$ \\
\hline rhyolite & 9.3 & $1.55 \times 10^{-3}$ & best \\
\hline breccia tuff & 8.18 & $0.08 \times 10^{-3}$ & good \\
\hline trachyte、 andesite & 6.68 & $0.068 \times 10^{-3}$ & poor \\
\hline
\end{tabular}

Through the statistical analysis of porosity and density of volcanic reservoirs shows that volcanic rocks can be used as reservoirs when their density is less than $2.53 \mathrm{~g} / \mathrm{cm}^{3}$. According to the relationship between the size of reservoir space, gas content, and the characteristics of volcanic rocks such as lithology, facies and reservoir space, the reservoirs in this area are divided into the following four categories (Fig. 1) [5].

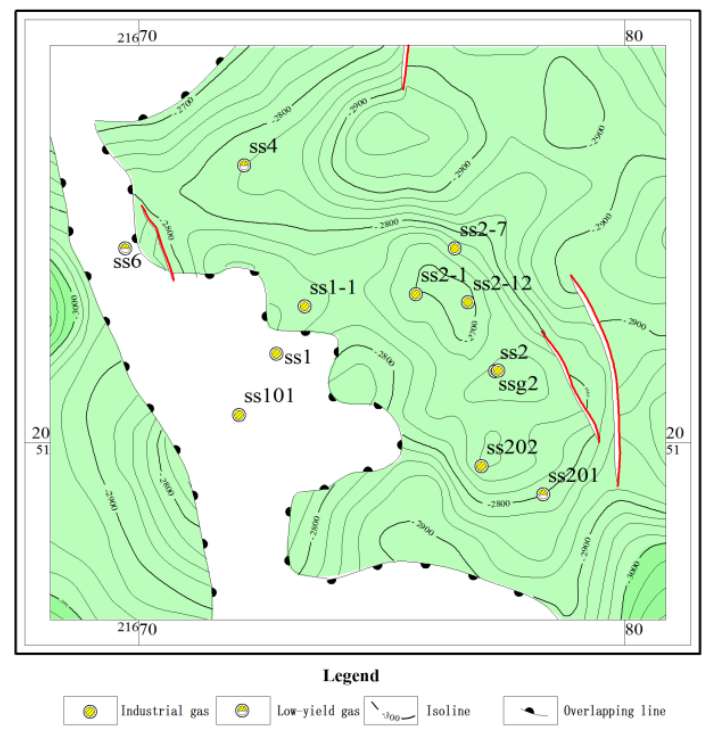

Fig. 1. Distribution of volcanic lithofacies in Yingcheng formation of Block Shengshen2-1.

\subsection{Primary reservoir}

The lithology is mainly rhyolite and fused tuff, mainly the upper of eruption facies. The storage space is micro-crack and primary pores, with porosity greater than $10 \%$ and permeability greater than $1.0 \times 10^{-3} \mu^{2}$, class A porethroat. It is mainly distributed around well shengshen2-1 and well shengshen-2, where natural gas testing capacity is above medium-high capacity.

\subsection{Secondary reservoir}

The lithology is mainly rhyolite, volcanic breccia and tuff, mainly composed of volcanic channel facies, thermoclastic flow subfacies, and lower subfacies of gushing facies. The storage space is microfracture, primary small pores, Intergravel pores and intergravel pores, volcanic ash dissolved pores, with porosity of 8.0 $10.0 \%$ and permeability of $0.5-1.0 \times 10^{-3} \mu \mathrm{m}^{2}$, class A or class B pore-throat. Natural gas testing capacity is not high, but higher production can be achieved after fracturing. These reservoirs are mainly distributed around well shengshen 2-7 and well shengshen 202.

\subsection{The 3rd reservoir}

The lithology is mainly rhyolite and tuff, mainly hydroclastic flow subfacies and the lower of eruption facies. The storage space is micro cracks, small pores and volcanic ash dissolved pores, with porosity of $5.0-8.0 \%$ and permeability of $0.1-0.5 \times 10^{-3} \mu \mathrm{m}^{2}$, class B pore-throat. Mostly can achieve industrial gas after fracturing.

\subsection{The 4th reservoir}

The lithology is mainly rhyolite and tuff, with porosity of $4.0-5.0 \%$ and permeability of $0.01-0.1 \times 10^{-3} \mu \mathrm{m}^{2}$, class $\mathrm{C}$ or class D pore-throat. Can't achieve industrial gas after fracturing.

\section{4 conclusion}

The reservoir space of Yingcheng formation volcanic rocks in block Shengshen 2-1 is mainly composed of primary blowhole and dissolution pores. Primary macropores are the main reservoir spaces of high production wells. Fractures are not developed in the blowhole section. The radius of pore throat has a great influence on natural gas production. Reservoirs in the gasproducing section in this area are mainly of Secondary reservoirs and The 3rd reservoirs, and Primary reservoirs are few. In order to obtain higher production, fracturing must be carried out.

\section{References}

1. Wang Zhiguo, Accumulation anlysis of volcanic gas reservoir in Yingcheng formation of Block Shengshen2-1 of Northern Part of Songliao Basin (Inner Mongolia Petrochemical Industry, 2013, p135140 )

2. Xie Hao, Reservoir Characteristics of Deep Volcanic Gas Reservoirs in Anda Depression (Western Prospecting Project, 2016, p77-80 )

3. Chen Huanqing, $\mathrm{Hu}$ Yongle etc. Tracing and Identifying of Volcanic Bodies and Their Application on the Effective Exploitation of Gas Reservoir (Journal of Earth Sciences and Environment, 2016, p494-504 )

4. $\mathrm{Hu} \mathrm{Bo}$, Reserve parameters of Yingcheng Formation volcanic gas reservoir in Xushen gas field (Inner Mongolia Petrochemical Industry, 2018,p114-18 ) 
5. Wang Ying, Deng Shouwei, etc. Natural Gas Geoligy, resource potential and favorable exploration direction in the south of Songliao Basin (Natural Gas Geoscience, 2018, p1455-1464 ) 